\title{
JSE LISTED COMPANIES IN THE FOOD AND DRUG RETAIL SECTOR: A CONTENT ANALYSIS OF FINANCIAL STATEMENTS TO DETERMINE THEIR PRIMARY PURPOSE
}

\author{
Vanessa Gregory* \\ University of KwaZulu-Natal
}

Received: April 2016

\author{
Mihalis Chasomeris" \\ University of KwaZulu-Natal
}

Accepted: July 2016

\begin{abstract}
The overall purpose of the study is to analyse financial statements to determine the primary purpose of JSE listed companies in the food and drug retail sector. There were two parts to the analyses. First, the study examines the literature on the three models, namely: neoclassical, conscious capitalism and entity maximisation and sustainability in order to identify themes or major identifiers of each model. Second, it analyses the financial statements (over five years from 2010 to 2014) of JSE listed companies in the food and drug retail sector, in particular the non-financial information. The entire population was analysed as there were only four in the population, namely SPAR, Pick $n$ Pay, Shoprite and Clicks. Annual integrated reports and sustainability reports (where separately published) were analysed using content analyses. Keywords and themes were used to link the attributes of the company to the attributes identified in the literature to determine the model the company used. The content analyses showed that the dominant model was the entity maximisation and sustainability model. However, each company appears to have chosen to focus on a different stakeholder: SPAR on employees, Pick n Pay on customers (with a differentiation strategy), Shoprite on customers (with a low cost strategy) and Clicks on shareholders.
\end{abstract}

Keywords

Stakeholder orientation, sustainability reporting, profit maximisation, entity maximisation, triple bottom line, food and drug retail sector

\footnotetext{
*Mrs V Gregory is a lecturer in the School of Accounting, Economics and Finance, University of KwaZulu-Natal, South Africa, [gregoryv@ukzn.ac.za].

"Dr M Chasomeris, is a senior Lecturer in the Graduate School of Business and Leadership, University of KwaZulu-Natal, South Africa.
} 


\section{INTRODUCTION}

Over the years there have been varying approaches to running businesses, resulting in many different goals, aims and schools of thought pertaining to what the ultimate goal or purpose of an entity should be. There has been much research and published literature on models that can be followed by businesses but they ultimately boil down to three types of models. The first of these, the neoclassical model, indicates that the main purpose of an entity is to make profits and therefore the focus solely on the shareholders (Vranceanu, 2014). The second one, conscious capitalism (CC), is trending in America at present and differs to neoclassical in that the focus turns from shareholders to all stakeholders and has the business focusing on a higher purpose as opposed to profits (Mackey, 2011). The last model, entity maximisation and sustainability (EMS), differs slightly to $C C$ in that only part of the focus is maximising entity wealth (which positively impacts all stakeholders), the other part of the focus being sustaining the business in the long term (Høgevold, Svensson, Wagner, Petzer, Klopper, Varela, Padin \& Ferro, 2014).

Within the literature explored on these three models, there was no identified exploration into South African companies and what they followed. Furthermore, although the literature did explore the pitfalls and merits of each model, it was unclear which model was favoured. The purpose of this study is therefore to identify within a South African context (in this instance, the food and drug retail sector as listed on the JSE) which model companies are purporting to follow through an inspection of annual financial reports. The research objectives linked to this purpose include: to examine the literature on the three models (neoclassical, CC and EMS) in order to identify themes or major identifiers of each model, to examine the financial statements (over five years from 2010 to 2014) of JSE listed companies in the food and drug retail sector, in particular the non-financial information, for themes that could link to the identification of any of the three models and to prepare a content analysis based on this examination to draw a conclusion on which model each company in the population appears to be following.

The methodology used in this paper was content analyses. A detailed literature review was conducted using secondary data from journals, books and electronic sources that provided insight into the three models in order to establish themes related to each model. These themes were then used to perform the content analysis of non-financial information within published annual reports of the four entities listed within the chosen sector from 2010 to 2014 . The listed entities are SPAR, Pick n Pay, Shoprite and Clicks. This analysis led to a conclusion on the model followed by each company within the sector.

The paper is structured as follows. Section 2 reviews the literature on the three models and compares and contrasts their approaches. Section 3 discusses the research methodology used and collection of the data. Section 4 discusses the results and findings from the content analyses. Section 5 concludes the study.

\section{LITERATURE REVIEW}

Key findings of the literature reviewed are discussed under the following headings. 


\subsection{Neoclassical Model}

The neoclassical model has been a continuing viewpoint embraced by economists world -wide. Its foundation in classical economics was initiated after Adam Smith wrote The Wealth of Nations in 1776 (Schiller, 2011). The principles that were suggested, and have been at the forefront of economics from that time, were that of profit maximisation by businesses and utility maximisation by consumers. Essentially, the model was of supply and demand and showed equilibrium for profit maximisation, where a firm's marginal revenue is equal to marginal cost. He proposed that if a market was out of a state of equilibrium, the 'invisible hand' within the market would assist in returning that market back to equilibrium otherwise it would have resulted in either a surplus or deficit within the market (Schiller, 2011). Effectively, Smith's view was that selfinterested behaviour by individuals and firms would result in moral outcomes for society as a whole (Jones and Felps, 2013). Abdur-Rahman (2011) noted that one of the most significant assumptions of the model was that profits were maximised by businesses, and that businesses would therefore only produce at equilibrium output in order to guarantee that profits were maximised. However, this did not represent an everyday life situation as the model did not account for such things as time differentials between when costs were sustained and revenues were received and that perfect information was not close at hand either. However, Loderer, Roth, Waelchli and Joerg (2010) state that some assumptions under Smith's model, such as complete markets, price-taking behaviour, perfect information and zero transaction costs, are rarely met in a real-world scenario. Regardless of this disagreement with the model, there was still, however, agreement that the primary objective of any business was to maximise profits.

Ireland (2005), Jones and Felps (2013), Loderer et al. (2010) and Magaro (2010) refer to the model as the shareholder / stockholder model. They proposed that the goal in such a model was solely to maximise profits; profits would then maximise business market value, thereafter result in a maximisation of owner or shareholder wealth. This model is thus referred to as the shareholder model. Corporate social responsibility (CSR) undertakings would therefore not be incorporated unless shareholders ultimately benefited from such activities (Vranceanu, 2014), regardless of benefits that might be experienced by others in society (Queen, 2015).

This proposed outlook, however, was seen by Keay (2008) to be a very short-term focus and therefore would not keep a business going in the long term. Stout (2013) supported this view, as evidence showed that directors would cut expenditure in marketing and product development if it was necessary to reach their earnings targets despite the fact that long-term performance might be adversely affected. The immediate consequences of these short-term decisions, by directors, often undermine the ongoing ability to create shareholder value (Jones and Felps, 2013). Halburd (2014) showed that the model destroyed shareholder value and resulted in the life span of businesses being reduced over the past thirty years.

Despite these reservations, other studies such as those by Elson (2010) and Magaro (2010) produce evidence as to why the shareholder-focused model should still be adopted by businesses. The main support is with reference to the fact that shareholders are owners of businesses and that they in turn receive a residual claim on the business. Magaro (2010) explains that shareholders technically place directors as trustees over their property (being the business) and therefore directors have a duty towards them before any other people. Other stakeholders, such as creditors and employees, usually have contracts in place with a business and, as a result, they have fixed claims against the business, and, in the event that the contract was breached, remedies could be sought through the legal system (Sundaram and Inkpen, 2004). Shareholders, on the other hand, do not have the same recourse and are the last to receive their claim on the business; they 
succumb to any losses and enjoy any gains the business has experienced (Magaro, 2010). Further to this, if shareholders are not focused on, Elson (2010) indicates that investors will then not be keen to invest and therefore companies would have to rely more on debt and current earnings for funding and as such the capital system would be greatly affected. Sundaram and Inkpen (2004) also indicate that by focusing only on shareholders, the business will not end up focusing on benefiting another group at the expense of the wellbeing of the business. This being so, within the shareholder group there will be various individual interests being represented and conflict could occur within the shareholder group, where some shareholders are focused on short-term profits (as they are trading) while others are interested in long-term profits (as they are investing) (Stout, 2013). Keay (2008) and Jones and Felps (2013), however, are of the view that many stakeholders are affected by a business's actions and that focusing merely on shareholder interests can result in depriving another stakeholder, which could in turn have detrimental sideeffects on the business.

The shareholder model discussed above would be unsuccessful in considering any other values infused in a business other than to become productive, efficient and profit maximising (Keay, 2008). Therefore other models needed to be investigated that involved other stakeholders. The next model discussed, CC (also referred to as the stakeholder model), incorporates all such stakeholders.

\subsection{Conscious Capitalism (CC)}

The $\mathrm{CC}$ model illustrates a viewpoint that entrepreneurs have begun to support in the last few years and has been growing in popularity in America in particular. Evidence does exist, however, showing similar models being followed by businessmen as early as the 1930s (Keay, 2008). The viewpoint emphasises a focus on all stakeholders of a business rather than just the owners and thus brings triple bottom line (profits, plant and people) into consideration (Coates, 2013). CSR was therefore a strong focus in entities that follow the $\mathrm{CC}$ model.

Wang (2013), Sisodia (2011), 0'Toole and Vogel (2011) and Mackey (2011) give four essential principles of $\mathrm{CC}$, namely higher purpose, stakeholder orientation, conscious leadership and conscious culture. Schawbel (2013) notes that all four principles need to be focused on equally, otherwise it would result in the entire system suffering in the long term and full potential not being achieved. These four principles are discussed below:

- Higher purpose: The higher purpose is of vital importance, as not only do the other three CC principles hinge on it, but it is the core of every business decision (Schawbel, 2013). It entails management widening their vision beyond profit maximisation and focusing on stakeholder co-operation to create value and enhance the business as a whole (Waligo, Clarke and Hawkins, 2014; Young-Ferris, 2015). It is usually stated as part of a company's mission statement to illustrate to a stakeholder what the business does, why it does it and what they are hoping to achieve by doing such actions (Sandling, 2014).

- Stakeholder orientation: All stakeholder prosperity should be maximised; therefore management need to consider simultaneous demands from multiple stakeholders without compromising one for the sake of another (Waligo et al., 2014; Sandling, 2014). Six major stakeholders were identified: customers, employees, suppliers, investors, society and the environment (Mackey, 2011).

- Conscious leadership: Conscious leadership embraces the higher purpose and creates a focus on creation of value through harmonising stakeholder needs (Mackey, 2011). Such leadership 
is delivered through mentoring, motivating, developing and inspiring people (Sisodia, 2011). Successful conscious leadership will result in the creation of a conscious culture (Sandling, 2014).

- Conscious culture: A conscious culture is created when cultures such as trust, truthfulness, caring, transparency, integrity, and learning and empowerment are implanted in the business to create a working environment that focuses on the higher purpose and strives towards those goals (Sisodia, 2011; Young-Ferris, 2015).

CC appeared to be the more attractive model, as more people benefited from the business rather than just the shareholders. However, there were fears about whether this was a proven fact. Sisodia's (2011) research revealed that, over a ten-year period ending 30 June 2006, CC companies outperformed the market, when considering their overall return on equity, by nine times. The indication was that the outperformances were likely due to lower levels of staff turnover and 'free' marketing, among other things (Aburdene, 2013). Wang (2013) did similar research to Sisodia (2011) and also found CC followers performed better, but only by 2.6 times. However, Amazon was identified as an outlier with a $365 \%$ return and was therefore excluded and thereafter it was found that the other businesses in the sample actually underperformed compared to the market. Sisodia (2013) still defends the principle, concluding that CC followers do have enhanced long-term performance but that they might not always show this due to still being subject to normal business fluctuations in a business cycle. Sundaram and Inkpen (2004) found that there was no clear relationship that shows whether performance is indeed better under a model such as CC. Omran, Atrill and Pointon (2002) also found that there was no significant difference in returns when comparing a shareholder-focused company to a stakeholder-focused company. It is very clear, therefore, that the literature is contradictory when considering the performance of the entities.

Entities that followed the CC principles were probably going to be involved in CSR activities because they would focus on looking after all stakeholders. Burke, Martin and Cooper (2011) show that $67 \%$ of business leaders in the United States had confidence that CSR made a significant contribution to net profits and $80 \%$ believed CSR added to the reputation of the business. Business profits would increase due to an increase in sales, growth in market share, decreased operating costs, better brand position, improved corporate image, a greater ability to draw in employees, motivate and secure them, and increased attraction to investors and financial analysts. Businesses would still have to incur costs on CSR in order to succeed in getting these benefits, and sometimes the benefits received did not always exceed this cost incurred. Budan (2013), however, reports from an interview with John Mackey that CSR was not equivalent to CC. Mackey maintained that CSR was a way for businesses to improve their reputation and that businesses that applied $\mathrm{CC}$ had built social responsibility into their purpose (part of their higher purpose) and therefore were inherently socially responsible and did not need separate CSR projects.

Another concern of $\mathrm{CC}$ was that one stakeholder's interest would differ from another stakeholder's interest, and it was therefore virtually impossible to please all stakeholders in the real world (0'Toole and Vogel, 2011). Magaro (2010) agreed with this sentiment, concluding that no one can serve two masters and emphasising that directors could end up making poor decisions as there is no real accountability. Rauch (2011) suggested, however, that stakeholders of a business should be treated as though they were comparable to organs in a human body. In certain decisions, one 'organ' (stakeholder) would need to be favoured over the other in order to ensure the proper functioning of the 'body' (business). Effectively, each 'organ' was aligned and optimised to ensure a properly, fully functional 'body' and the result was a win-win-win situation for all. Such a goal was essential in a business. Others, such as Sundaram and Inkpen (2004), Omran et al. 
(2002), Waligo et al. (2014), Sandling (2014) and Mackey (2011), still insist that all stakeholders' interests can be met and that despite stakeholder differences, a common goal can be found among them to ensure long-term success for the business and stakeholder happiness.

\subsection{Entity Maximisation and Sustainability (EMS)}

EMS, as a model, was suggested by Keay (2008), who argued that entrepreneurs should be focusing on maximising their own wealth rather than the wealth of any particular stakeholder, or group of stakeholders, while maintaining sustainability. He maintained that maximisation was not just measured through profits, as they were merely one part of business wealth and did not encompass wealth in its entirety. Maximisation would also benefit all stakeholders, as it would foster their common interests. The second part of the model was to maintain sustainability. The argument here was that, if sustainability was not upheld, the business would not survive in the long term (Keay, 2008). The origin of sustainability discussions goes further back than Keay's suggestion of the EMS model. According to Høgevold et al. (2014), scholars have been researching such issues since the 1960s. In 1987, sustainable development was defined as 'development that meets the needs of the present without compromising the ability of future generations to meet their own needs' (United Nations, 1987:54). This definition has been reiterated in several different studies on sustainability, including those by Šimanskienė and Paužuolienė (2010), Bocken, Short, Rana and Evans (2013) and Seay (2015). However, there is no universally accepted definition yet, as the concept is still evolving (Høgevold et al., 2014).

Seay (2015) explains that following a model that encompasses sustainability would result in a business not only recognising the importance of making profits and growing, but also pursuing societal, environmental and governance goals to achieve long-term value creation and success. Wagner and Svensson (2014) agree with Seay's explanation and add that from observation it appears that most definitions of sustainability share core elements that incorporate economic, social and environmental considerations, all three of which need to be balanced so that they mutually reinforce each other (Høgevold et al., 2014). Business models that incorporate sustainability go beyond simply delivering economic value and also incorporate value for a broader range of stakeholders (Bocken et al., 2013). A sustainability approach therefore encompasses the triple bottom line approach (Høgevold, Svensson, Klopper, Wagner, Valera, Padin, Ferro and Petzer, 2015).

The spheres of economic, social and environmental considerations incorporate many different aspects that businesses can focus on. Høgevold et al. (2015) and Dos Santos, Svensson and Padin (2014) provide a brief overview of what each pillar should be illustrating to any stakeholder of an entity:

- Economic pillar: A business should be illustrating its ability to be able to make profits.

- Environmental pillar: A business should be illustrating what impact it has on the environment. This entails showing how it has positively contributed to the environment as well as any negative impacts and how these have been improved or negated in later years.

- Social pillar: The social pillar should comprehend social interactions and values that the business has with people both internally and externally. This is perhaps the most difficult to show comprehensively, so most organisations illustrate this through CSR.

Seay (2015) explained that businesses are following the sustainability model, as it creates more value within a company, which reaches all stakeholders. In this it is different to other models that focus on either just one stakeholder or a handful of stakeholders. The investment in such business 
practices is therefore warranted, as benefits flow to the business as well as to stakeholders (Dos Santos et al., 2014). Benefits that have been derived from sustainability efforts can be summarised into three broad themes:

- Improved company/brand image leading to competitive advantage: Consumers have a large impact on how the business performs, as, without them, the business will not be successful (Jones and George, 2011). It has been shown that consumers respond more positively to good company sustainability and commitment to economic sustainability and that some customers even pay a premium for such products resulting in market share growth for that company (Seay, 2015, Šimanskienè and Paužuolienè, 2010).

- Cost savings: Cost savings are achieved through various avenues, but the most direct saving is through reducing items such as waste, energy, water and emissions (Seay, 2015).

- Enhanced employee recruitment and retention: Robbins, Judge, Odendall and Roodt (2011) indicate that businesses that foster a favourable working environment through any means will result in a happy workforce. They further state that if you have a happy workforce there would be less employee turnover and the business would be able to recruit expertise easily, as they would be an employer of choice, both resulting in cost saving (Seay, 2015).

Despite all the evidence showing how sustainability creates value, Høgevold et al. (2015) say that measuring performance is not necessarily an easy task. Certain measures are easy to quantify as there are standard measures that can be applied to each and every company relatively easily, but most social and environmental activities that a business undertakes are unique and therefore are difficult to quantify using a standard measure (Høgevold et al., 2015).

There has been an increased focus on sustainability in order to achieve long-term growth in business. Seay (2015) states that issues of sustainability have become of increasing concern to humanity and for that reason sustainability has escalated into a central business concern. Lamb, Hair, McDaniel, Boshoff, Terblanche, Elliot and Klopper (2010) also emphasise that customers are very aware of their impact on the environment as a result of consuming different products, and it will inevitably become difficult to sell items that are not environmentally friendly. The Global Reporting Initiative was therefore formed in the 1990s in order to explore sustainability issues and how progress and goals related to these issues can be reported to users. This research has expanded from general sustainability issues to industry-specific ones and in future companies (especially those listed on a securities exchange) are likely to have to report on such considerations (Global reporting initiative, 2015).

\section{RESEARCH METHODOLOGY}

The study followed a qualitative approach, using content analysis to determine findings and make conclusions. Content analysis entails the derivation of themes or categories from literature in order to apply data to the categories during the analysis stage. As part of this study, literature has been reviewed and presented in section 2. From this review it was evident that each possible primary objective of a company had a different focus; however, each focus entailed a focus on either some, all, or just one stakeholder. As a result, different stakeholders became the main themes to consider, six of which were identified: customers (consumers), employees (staff), suppliers, investors (shareholders), general society (community) and the environment.

Frequencies for each mention of such stakeholders in non-financial sections of the company's annual integrated report from 2010 to 2014 were recorded in order to ascertain a relativity of 
importance in accordance with the content analysis methodology. When considering frequencies, synonyms as identified in the literature have been grouped together and pronouns have been ignored due to the fact that such pronouns could replace any noun and not just a single stakeholder. Most companies reported similar reporting information, with the exception being the remuneration report that was produced only by Clicks (2010 to 2014) and Pick n Pay (2012 to 2014). Therefore in considering non-financial information the researchers decided to leave out the remuneration report to prevent a bias towards employees for those companies. As it is in the opinion of the researchers that such frequencies were not solely sufficient to draw a final conclusion, the financial statements were read in more detail to explore what each company was saying about, and doing for, each stakeholder. The frequencies and narrative were then considered to ascertain the extent of focus on each stakeholder. Where the extent of focus was solely on the investor, this was evidence of the neoclassical model and where the focus was divided among the different stakeholders, either EMS or CC was evidenced. To distinguish between EMS and CC, where an entity focused on sustainability of the entity and its wealth rather than only maximising stakeholder wealth, then EMS would apply. Therefore a further theme of sustainability was explored in the same manner as the stakeholders, before drawing a conclusion on the approach followed.

The population of the chosen sector (food and drug retailers) on the JSE comprises five different companies, namely: SPAR, Pick n Pay Holdings, Pick n Pay Stores, Shoprite and Clicks. Upon further investigation it was noted that Pick $n$ Pay Holdings' sole purpose was to hold a controlling share in Pick n Pay Stores (Pick n Pay, 2010) and the financial statements are presented in one consolidated document. Therefore both companies have been treated as one, resulting in four companies in the sector that represent the population, all of which have been analysed in this study.

\section{FINDINGS AND DISCUSSIONS}

In the findings below, each company has been analysed from 2010 to 2014 using content analysis. TABLE I (SPAR), TABLE 6 (Pick n Pay), TABLE 11 (Shoprite) and TABLE 15 (Clicks) all illustrate the frequencies of mentions of the six main stakeholders (F) and their relative frequencies to the total mentions over the period (\%). These tables are then supported by a narrative on each stakeholder and on sustainability, to reach the conclusions shown in Section 5.

\subsection{SPAR}

\subsubsection{Stakeholders}

SPAR considers stakeholder needs and the value they bring to the group. The chairman indicates that the group undertook discussions to 'ensure a deep understanding of the impact on all stakeholders' (SPAR, 2014:9) when considering a large transaction. In 2010, it was also indicated that 'the group understands the need to engage with its stakeholders who are not just interested in the financial aspects of the business, but are also interested in the social and environmental sustainability of the business' (SPAR, 2010:25). 
TABLE 1: SPAR stakeholder frequencies from 2010 to 2014

\begin{tabular}{ccccccccccccc}
\hline & \multicolumn{2}{c}{2014} & \multicolumn{2}{c}{2013} & \multicolumn{2}{c}{2012} & 2011 & \multicolumn{2}{c}{2010} & \multicolumn{2}{c}{ Total } \\
\hline & $F$ & $\%$ & $F$ & $\%$ & $F$ & $\%$ & $F$ & $\%$ & $F$ & $\%$ & $F$ & $\%$ \\
\hline $\begin{array}{c}\text { Customers/ } \\
\text { Consumers }\end{array}$ & 58 & $18 \%$ & 32 & $17 \%$ & 37 & $17 \%$ & 30 & $17 \%$ & 16 & $13 \%$ & 173 & $17 \%$ \\
$\begin{array}{c}\text { Employees/ } \\
\text { Staff }\end{array}$ & 86 & $27 \%$ & 53 & $29 \%$ & 43 & $19 \%$ & 47 & $27 \%$ & 40 & $32 \%$ & 269 & $26 \%$ \\
$\begin{array}{c}\text { Investors/ } \\
\text { Shareholders }\end{array}$ & 21 & $7 \%$ & 22 & $12 \%$ & 32 & $14 \%$ & 25 & $14 \%$ & 14 & $11 \%$ & 114 & $11 \%$ \\
$\begin{array}{c}\text { Society/ } \\
\text { Community }\end{array}$ & 32 & $10 \%$ & 21 & $11 \%$ & 43 & $19 \%$ & 23 & $13 \%$ & 16 & $13 \%$ & 135 & $13 \%$ \\
\hline Supplier & 64 & $20 \%$ & 30 & $16 \%$ & 24 & $11 \%$ & 17 & $10 \%$ & 10 & $8 \%$ & 145 & $14 \%$ \\
\hline $\begin{array}{c}\text { Environment } \\
\text { Total }\end{array}$ & 62 & $19 \%$ & 26 & $14 \%$ & 45 & $20 \%$ & 32 & $18 \%$ & 29 & $23 \%$ & 194 & $19 \%$ \\
\hline Source:Authors & & $100 \%$ & 184 & $100 \%$ & 224 & $100 \%$ & 174 & $100 \%$ & 125 & $100 \%$ & 1030 & $100 \%$ \\
\hline
\end{tabular}

Source: Authors compiled using data from SPAR (2010; 2011; 2012; 2013; 2014)

\section{- Customers}

SPAR operates on a voluntary trading structure, meaning that each SPAR store is individually owned and not owned by SPAR itself. SPAR therefore has direct customers (being the retailers who own the stores under the trading structure) and also has indirect customers (those who shop at the retail stores), both of which are an important focus, as retaining the indirect customers results in more being supplied to the retailers. Furthermore, retailers are not obliged to procure all their products from the SPAR distribution centres; therefore there is a need to focus on the direct customer relationship in order to retain their procurement. Resources have been committed to both types of customers.

One of SPAR's strategic focuses is retailer support, ensuring that measures are in place to aid retailer success as part of their mission. Support services such as assisting retailers to make their stores appealing to customers through design and revamp assistance, encouraging merchandising best practice, assisting with public relations activities, and offering other training where necessary are some support mechanisms available to retailers (SPAR, 2014). In 2012 more than R9 million was invested to assist in developing skills at retailers that would enhance customer service (SPAR, 2012). Over and above this, for all five years analysed, SPAR had an in-house customer care line to address any customer complaints as well as queries relating to all products sold at retailer stores. Consumer surveys and focus groups were also held at retail store levels to gain feedback to continue to deliver quality products to their indirect consumer as well as aid retailers to improve their services (SPAR, 2011).

\section{- Employees}

Employees are key to SPAR and as such they have strived to ensure employee satisfaction (SPAR, 2013), being named top employer in South Africa for 2014 and not being subject to much strike action (SPAR, 2014). In-house training is made available not only to SPAR staff, but SPAR retailer staff too (SPAR, 2012). Training and development programmes are focused on leadership, management, supervision and graduate trainees. Other training includes technical training (computer skills, driver training and first aid) and health and safety training. Wellness services 
are provided through onsite clinics on which an increasing amount of money has been invested each year (from 2 million in 2010 to 3 million in 2014). HIV/AIDS awareness campaigns have been launched, and these have been accompanied by counselling and support for HIV-positive employees. SPAR has also committed itself to transformation, targeting level 3 BBBEE status, but only achieving level $6(2010,2011,2012)$ or 7 (2014) status.

- Suppliers

SPAR works in partnership with its suppliers (SPAR, 2014) as it believes that strong collaborative relationships are important (SPAR, 2011). Partnership initiatives include reducing packaging, creating transport efficiencies, maintaining low prices and even some social investment projects. Suppliers are audited to ensure compliance with SPAR standards. Farmers have been trained on sustainable farming methods, growing from 21 farmers (SPAR, 2011) to 41 farmers (SPAR, 2014). Sourcing from local suppliers in the first instance has also been prioritised (SPAR, 2010).

- Investors (Shareholders)

SPAR highlighted performance statistics for shareholders to illustrate the growth in the company and value given back to shareholders (see TABLE 2).

TABLE 2: SPAR performance statistics from 2010 to 2014

\begin{tabular}{lccccc}
\hline & 2014 & 2013 & 2012 & 2011 & 2010 \\
\hline $\begin{array}{l}\text { \% increase in turnover } \\
\text { \% increase in headline earnings per }\end{array}$ & $15 \%$ & $9.8 \%$ & $12.2 \%$ & $10.4 \%$ & $9 \%$ \\
share & $12.5 \%$ & $13 \%$ & $10.6 \%$ & $3.9 \%$ & $12.1 \%$ \\
\hline $\begin{array}{l}\text { Dividends per share } \\
\text { 5 }\end{array}$ & $540 \mathrm{c}$ & $485 \mathrm{c}$ & $430 \mathrm{c}$ & $377 \mathrm{c}$ & $362 \mathrm{c}$ \\
\hline
\end{tabular}

Source: Authors compiled using data from SPAR (2010; 2011; 2012; 2013; 2014)

- General Society

SPAR has contributed to society through various CSR initiatives, some of which benefit general society as well as other specific stakeholders. Broad focus areas have been on healthcare, hunger, poverty alleviation, safety and sports. CSR spend has increased over the years, but relative to net profits and revenues, it has been maintained (see TABLE 3).

TABLE 3: SPAR CSR spending from 2010 to 2014

\begin{tabular}{lccccc}
\hline & 2014 & 2013 & 2012 & 2011 & 2010 \\
\hline CSR spend (R millions) & 13.2 & 11.8 & 11.4 & 9.6 & 9.3 \\
CSR spend as a \% of revenue & $0.024 \%$ & $0.025 \%$ & $0.026 \%$ & $0.025 \%$ & $0.027 \%$ \\
CSR spend as a \% of net profits & $0.981 \%$ & $0.991 \%$ & $1.077 \%$ & $1.008 \%$ & $1.016 \%$ \\
\hline
\end{tabular}

Source: Authors compiled using data from SPAR (2010; 2011; 2012; 2013; 2014)

\section{- Environment}

The group has created an environmental policy that focuses on reducing the negative impact of operations and making a positive contribution to preservation of the environment (SPAR, 2010). 
In 2012 a three-day children's conference was held to educate children on environmental issues (SPAR, 2012). In 2013 specific goals were set with reference to reduction in electricity consumption, fuel emissions, waste to landfills and municipal water use (SPAR, 2013). These have been monitored and in 2014 reflected as a $25 \%$ reduction in electricity usage, $14 \%$ reduction in total carbon footprint, more usage of biodiesel, rain water recycling and a new trailer prototype designed to reduce fuel costs and carbon dioxide emissions (SPAR, 2014). TABLE 4 summarises environmental initiatives undertaken.

TABLE 4: SPAR environmental initiatives from 2011 to 2014

\begin{tabular}{lcccc}
\hline & 2014 & 2013 & 2012 & 2011 \\
\hline Energy consumed (kilowatt hours) & 37696714 & 49999540 & $\begin{array}{c}\text { Not } \\
\text { quantified }\end{array}$ & 75925352 \\
Recycling - cardboard (metric tonnes) & 9995 & 9241 & 6477 & 2973 \\
Recycling - plastic (metric tonnes) & 1037 & 925 & 569 & 282 \\
\hline
\end{tabular}

Source: Authors compiled using data from SPAR (2010; 2011; 2012; 2013; 2014)

\subsubsection{Sustainability}

SPAR's prevailing purpose has been 'To provide expert leadership and support to retailers to enable them to run sustainably profitable and professional business' (SPAR, 2014:2). In furtherance of its purpose, SPAR indicates that 'focus is on stakeholder returns through a sustainable system' (SPAR, 2014:39) and has ensured that sustainability thinking has been integrated into all aspects of its strategy. As a consequence of this chosen purpose, certain values are encompassed in its business model, including ones directly aimed at certain stakeholders and having a long-term focus. Sustainability has been an increasing focus for SPAR (see TABLE 5).

TABLE 5: SPAR sustainability frequencies from 2010 to 2014

\begin{tabular}{lccccc}
\hline & 2014 & 2013 & 2012 & 2011 & 2010 \\
\hline Frequency of 'sustain' & 100 & 72 & 48 & 31 & 23 \\
\hline
\end{tabular}

Source: Authors compiled using data from SPAR (2010; 2011; 2012; 2013; 2014)

\subsection{Pick n Pay}

\subsubsection{Stakeholders}

Pick $n$ Pay is committed to continuing and expanding its engagement with stakeholders each year (Pick n Pay, 2014) as, with this stakeholder focus, shared value can grow (Pick n Pay, 2013). The company produces a bi-annual sustainable living report which further emphasises its involvement with stakeholders. 
Gregory \& Chasomeris

TABLE 6: Pick n Pay stakeholder frequencies from 2010 to 2014

\begin{tabular}{lcccccccccccc}
\hline & \multicolumn{2}{c}{2014} & \multicolumn{2}{c}{2013} & \multicolumn{2}{c}{2012} & \multicolumn{2}{c}{2011} & \multicolumn{2}{c}{2010} & \multicolumn{2}{c}{ Total } \\
\hline & $F$ & $\%$ & $F$ & $\%$ & $F$ & $\%$ & $F$ & $\%$ & $F$ & $\%$ & $F$ & $\%$ \\
\hline $\begin{array}{l}\text { Customers/ } \\
\text { Consumers }\end{array}$ & 216 & $40 \%$ & 112 & $38 \%$ & 86 & $35 \%$ & 60 & $29 \%$ & 43 & $33 \%$ & 517 & $36 \%$ \\
$\begin{array}{l}\text { Employees } \\
\text { Staff }\end{array}$ & 56 & $10 \%$ & 35 & $12 \%$ & 21 & $9 \%$ & 40 & $19 \%$ & 34 & $26 \%$ & 186 & $13 \%$ \\
$\begin{array}{l}\text { Investor } \\
\text { Shareholder }\end{array}$ & 108 & $20 \%$ & 66 & $22 \%$ & 44 & $18 \%$ & 49 & $23 \%$ & 34 & $26 \%$ & 301 & $21 \%$ \\
$\begin{array}{l}\text { Society } \\
\text { Community }\end{array}$ & 71 & $13 \%$ & 23 & $8 \%$ & 26 & $11 \%$ & 16 & $8 \%$ & 4 & $3 \%$ & 140 & $10 \%$ \\
\hline $\begin{array}{l}\text { Supplier } \\
\text { Environment }\end{array}$ & 47 & $9 \%$ & 36 & $12 \%$ & 30 & $12 \%$ & 27 & $13 \%$ & 9 & $7 \%$ & 149 & $10 \%$ \\
\hline Total & 542 & $100 \%$ & 294 & $100 \%$ & 243 & $100 \%$ & 209 & $100 \%$ & 132 & $100 \%$ & 1420 & $100 \%$ \\
\hline
\end{tabular}

Source: Authors compiled using data from Pick n Pay (2010; 2011; 2012; 2013; 2014)

\section{- Customers}

Pick $\mathrm{n}$ Pay has three enduring business principles that it follows, one of them being customer sovereignty. It holds that 'the customer is queen' (Pick n Pay, 2010:6) and has therefore appointed a customer director to gain customer feedback from various channels. Pick n Pay 'puts customers at the heart' of its business and creates value for this stakeholder (Pick n Pay, 2014:11). At the end of the 2011 financial year, Pick n Pay launched its smart shopper loyalty programme, which claims to be the biggest loyalty programme in South Africa (Pick n Pay, 2012). The number of card holders after the first year of the programme sat at just over five million and had escalated to almost eight million by the end of the 2014 financial year, rewarding customers with points so they can reap savings themselves or transfer those savings to charitable affairs. A number of awards have been received, including most reputable retailer, most trusted retailer and South Africa's number one grocery store (Pick n Pay, 2014, 2013).

\section{- Employees}

In 2014 Pick n Pay employed approximately 50000 people (Pick n Pay, 2014) and placed high priority on communication with these employees. Examples of how communication is effected include management updates, employee surveys, monthly publications, in-house television, inhouse radio, training and unions. Pick $\mathrm{n}$ Pay is committed to developing the skills of employees and has spent an increasing amount on training and bursaries over the period under review ( 55.2 million in 2010 increasing to 91.7 million in 2014). There are over 330 employee training programmes and in 2014 its own graduate recruitment programme was launched.

\section{- Suppliers}

Pick $\mathrm{n}$ Pay is passionate about supporting local suppliers, and has a particular focus on helping develop small businesses into becoming successful suppliers. Private label products sourced locally have increased from $88 \%$ (Pick n Pay, 2012) to $92 \%$ (Pick n Pay, 2014). A Small Business Incubator has also been developed where senior managers in the group are involved in ongoing mentorship of smaller entities - there are currently 72 of them (Pick n Pay, 2013) - to help develop 
them into suppliers. In 2014 R33 million was spent on technical support for suppliers, and all suppliers were subject to health, safety and environmental audits (Pick n Pay, 2014).

\section{- Investors (Shareholders)}

Pick $n$ Pay highlighted performance statistics for shareholders to illustrate the growth in the company and value given back to shareholders (see TABLE 7). Pick n Pay also held an investment day in August 2013 to give shareholders an update on its strategies (Pick n Pay, 2014). It has an open-door policy when it comes to its shareholders (Pick n Pay, 2011).

\section{TABLE 7: Pick n Pay performance statistics from 2010 to 2014}

\begin{tabular}{lccccc}
\hline & 2014 & 2013 & 2012 & 2011 & 2010 \\
\hline $\begin{array}{l}\text { \% increase in turnover } \\
\text { \% increase / (decrease) in headline earnings }\end{array}$ & $7.7 \%$ & $7.1 \%$ & $8.1 \%$ & $5.9 \%$ & $9.8 \%$ \\
$\begin{array}{l}\text { per share } \\
\text { Dividends per share }\end{array}$ & $44.3 \%$ & $(30.9) \%$ & $(13.5) \%$ & $(22.9) \%$ & $2.1 \%$ \\
\hline
\end{tabular}

Source: Authors compiled using data from Pick n Pay (2010; 2011; 2012; 2013; 2014)

\section{- General Society}

Pick n Pay engages with society through various CSR programmes that benefit both general society and other stakeholders in partnership with the Ackerman Pick n Pay Foundation (Pick n Pay, 2013). Examples of on-going projects during the period analysed include development of community gardens, donations of food and money to charities, assisting schools with educational material and small enterprise support. The total CSR spend has fluctuated over the years in actual amount and relative to revenue and net profits (see TABLE 8).

TABLE 8: Pick n Pay CSR/CSI spending from 2010 to 2014

\begin{tabular}{lccccc}
\hline & 2014 & 2013 & 2012 & 2011 & 2010 \\
\hline CSI spend (R millions) & 36 & 39.5 & 75.6 & 54.4 & 61 \\
CSI spend as a \% of revenue & $0.057 \%$ & $0.067 \%$ & $0.137 \%$ & $0.106 \%$ & $0.124 \%$ \\
CSI spend as a \% of net profits & $6.191 \%$ & $7.199 \%$ & $6.799 \%$ & $6.943 \%$ & $5.133 \%$ \\
\hline
\end{tabular}

Source: Authors compiled using data from Pick n Pay (2010; 2011; 2012; 2013; 2014)

\section{- Environment}

Pick $\mathrm{n}$ Pay has focused on lowering its carbon footprint through reduction of energy usage as well as recycling, and it has been successful in this (see TABLE 9). Some achievements made in its environmental performance include being the highest-ranked retailer on Carbon Disclosure Project's Climate Performance and Leadership Index in 2014, having its climate change strategy assessed as foremost among African businesses (Pick $n$ Pay, 2014) and receiving awards, including most environmentally responsible South African retailer, grand prix winner for green awareness and most innovative environmental strategies. R55 million was invested in energyefficient projects in 2014 . 
Gregory \& Chasomeris

TABLE 9: Pick n Pay Environmental Initiatives from 2010 to 2014

\begin{tabular}{lccccc}
\hline & 2014 & 2013 & 2012 & 2011 & 2010 \\
\hline Waste recycled (tonnes) & 18591 & 13611 & 12456 & 6444 & $\begin{array}{c}\text { Not } \\
\text { quantified }\end{array}$ \\
$\begin{array}{l}\text { Energy use (gigawatt hours) } \\
\begin{array}{l}\text { Carbon dioxide emissions } \\
\text { (tonnes) }\end{array}\end{array}$ & 510 & 517 & 530 & 557 & 569 \\
\hline
\end{tabular}

Source: Authors compiled using data from Pick n Pay (2010; 2011; 2012; 2013; 2014)

\subsubsection{Sustainability}

One of its values and beliefs in relation to business principles is that 'doing good is good business' (Pick n Pay, 2013:13): in other words, the growth of a company flows from doing good business. Pick n Pay (2012) emphasises that, by applying these principles, a solid platform will be formed for a sustainable business. It has been acknowledged that stakeholders have conflicting needs; however, the only way to ensure long-term sustainability is to balance the relevant stakeholder interests and ensure that a mutually beneficial relationship exists, and in 2014 this became a priority for Pick n Pay (Pick n Pay, 2014). In 2011, the CE0 stated in his report that 'sustainability has gained a foothold within our Company' (Pick n Pay, 2011:19), but evidence shows that the company has been committed to this business model since the early 1980s (Pick n Pay, 2013). The greater focus on sustainability, however, became evident only in 2011 (see TABLE 10).

TABLE 10: Pick n Pay sustainability frequencies from 2010 to 2014

\begin{tabular}{lccccc}
\hline & 2014 & 2013 & 2012 & 2011 & 2010 \\
\hline Frequency of 'sustain' & 86 & 85 & 81 & 82 & 39 \\
\hline
\end{tabular}

Source: Authors compiled using data from Pick n Pay (2010; 2011; 2012; 2013; 2014)

\subsection{Shoprite}

\subsubsection{Stakeholders}

Shoprite acknowledges that it is central to long-term success to effectively engage with key stakeholders to identify solutions to drive business forward as a mutual interest. It also understands that the business and the communities within which it operates are interdependent and cannot stand alone (Shoprite, 2013). 
TABLE 11: Shoprite Stakeholder frequencies from 2010 to 2014

\begin{tabular}{lcccccccccccc}
\hline & \multicolumn{2}{c}{2014} & \multicolumn{2}{c}{2013} & \multicolumn{2}{c}{2012} & 2011 & \multicolumn{2}{c}{2010} & \multicolumn{2}{c}{ Total } \\
\hline & $F$ & $\%$ & $F$ & $\%$ & $F$ & $\%$ & $F$ & $\%$ & $F$ & $\%$ & $F$ & $\%$ \\
\hline $\begin{array}{l}\text { Customers/ } \\
\text { Consumers }\end{array}$ & 72 & $26 \%$ & 68 & $24 \%$ & 71 & $26 \%$ & 75 & $32 \%$ & 185 & $33 \%$ & 471 & $29 \%$ \\
$\begin{array}{l}\text { Employees/ } \\
\text { Staff }\end{array}$ & 66 & $23 \%$ & 84 & $30 \%$ & 81 & $29 \%$ & 61 & $26 \%$ & 145 & $26 \%$ & 437 & $27 \%$ \\
$\begin{array}{l}\text { Investors/ } \\
\text { Shareholders }\end{array}$ & 56 & $20 \%$ & 61 & $22 \%$ & 55 & $20 \%$ & 22 & $9 \%$ & 30 & $5 \%$ & 224 & $14 \%$ \\
$\begin{array}{l}\text { Society/ } \\
\text { Community }\end{array}$ & 24 & $9 \%$ & 20 & $7 \%$ & 18 & $6 \%$ & 19 & $8 \%$ & 65 & $11 \%$ & 146 & $9 \%$ \\
\hline $\begin{array}{l}\text { Supplier } \\
\text { Environment }\end{array}$ & 34 & $12 \%$ & 26 & $9 \%$ & 30 & $11 \%$ & 38 & $16 \%$ & 84 & $15 \%$ & 212 & $13 \%$ \\
\hline Total & 282 & $100 \%$ & 281 & $100 \%$ & 277 & $100 \%$ & 235 & $100 \%$ & 567 & $100 \%$ & 1642 & $100 \%$ \\
\hline
\end{tabular}

Source: Authors compiled using data from Shoprite (2010; 2011; 2012; 2013; 2014)

- Customers

Shoprite values customers and their needs and as part of its strategy it has pinpointed one main customer need, low costs, and has geared itself to satisfying this need by successfully keeping its internal food inflation below the official food inflation rate (see TABLE 12), preventing over R1 billion worth of price increases from reaching customers in 2014 (Shoprite, 2014).

TABLE 12: Shoprite internal inflation versus official food inflation from 2010 to 2014

\begin{tabular}{lccccc}
\hline & 2014 & 2013 & 2012 & 2011 & 2010 \\
\hline Internal (Shoprite) inflation & $4.7 \%$ & $4.3 \%$ & $4.9 \%$ & $-0.1 \%$ & $2.2 \%$ \\
Official food inflation & $6.1 \%$ & $6.1 \%$ & $8.8 \%$ & $3.2 \%$ & $3.5 \%$ \\
Difference & $(1.4 \%)$ & $(1.8 \%)$ & $(3.9 \%)$ & $(3.3 \%)$ & $(1.3 \%)$ \\
\hline
\end{tabular}

Source: Authors compiled using data from Shoprite (2010; 2011; 2012; 2013; 2014)

In addition to ensuring low prices, Shoprite also ensures that customers have excellent service and sends staff for customer service training and training on the Consumer Protection Act. A customer feedback system has also been implemented to resolve any instances of negative feedback (Shoprite, 2011). From a customer point of view, AMPS (All Media and Products surveys) data has shown that Shoprite is valued by customers in that in 2010 Shoprite had the largest market share (Shoprite, 2010): 67\% of South Africa's adult population claimed to buy groceries from stores in the Shoprite Group in 2012 (Shoprite, 2012), increasing to $70 \%$ in 2013 (Shoprite, 2013), and in 2014 it recorded the highest number of loyal, regular customers (Shoprite, 2014). Shoprite was also rated the number one supermarket when considering overall customer experience in the Sunday Times Top Brands awards and the Times/Sowetan Retail Awards (Shoprite, 2014). 


\section{- Employees}

The Shoprite group is currently Africa's largest food retailer and employed 88000 individuals in 2010 (Shoprite, 2010) and 123000 in 2014 (Shoprite, 2014), an average annual increase of 7000 individuals. Shoprite therefore acknowledges that it is of the utmost importance to train employees and maintain employee satisfaction in order to retain staff. Staff turnover has remained under $20 \%$, favourable in comparison to the international industry average of $30.2 \%$, and Shoprite has also ensured that transformation has taken place within its business having gone from a level 6 BBBEE rating in 2010 (Shoprite, 2010) to a level 4 rating in 2014 (Shoprite, 2014). Shoprite too has been involved in training employees and furthering their skills and in 2014 it was one of the largest contributors to skills development in South Africa (Shoprite, 2014). Bursaries were also issued to deserving candidates in order for them to attain tertiary qualifications prior to working for the company. In addition, a number of learners are completing three- and 12month learnerships, and Shoprite has committed to employing $90 \%$ of the successful candidates (Shoprite, $2011 ; 2012 ; 2013)$. Employees can also take advantage of free voluntary counselling and testing for HIV/AIDS (Shoprite, 2011). In 2014 this benefit was extended so that all employees, and their immediate families, were covered by the post-exposure prophylactics medication programme in case of accidental exposure to the HI virus (Shoprite, 2014).

\section{- Suppliers}

Shoprite recognises top suppliers annually in an awards ceremony. Local suppliers are also utilised, as opposed to international suppliers, in order to support the country (Shoprite, 2013). This includes small farmers and other small businesses (Shoprite, 2010). One supplier describes the relationship with Shoprite as win-win, 'based on mutual respect and trust, with collaboration on logistics and planting programmes that enables proactive planning, forges mutual reliance and builds a long-term partnership' (Shoprite, 2014:25).

\section{- Investors (Shareholders)}

Shoprite highlighted performance statistics for shareholders to illustrate the growth in the company and value given back to shareholders (see TABLE 13).

\section{TABLE 13: Shoprite performance statistics from 2010 to 2014}

\begin{tabular}{lccccc}
\hline & 2014 & 2013 & 2012 & 2011 & 2010 \\
\hline $\begin{array}{l}\text { \% increase in turnover } \\
\text { \% increase in headline earnings per }\end{array}$ & $10.5 \%$ & $12.1 \%$ & $14.4 \%$ & $7.3 \%$ & $13.6 \%$ \\
$\begin{array}{l}\text { share } \\
\text { Dividends per share }\end{array}$ & $350 \mathrm{c}$ & $338 \mathrm{c}$ & $303 \mathrm{c}$ & $253 \mathrm{c}$ & $227 \mathrm{c}$ \\
\hline
\end{tabular}

Source: Authors compiled using data from Shoprite (2010; 2011; 2012; 2013; 2014)

- General Society

Shoprite engages with the general society through various initiatives. The annual reports did not quantify the amount of money spent on CSR activities; however, they did indicate that more than $1 \%$ of net profits after taxation was spent on such projects each year. Some of the projects focused on are food donations, a soup kitchen feeding scheme, and supporting young artists and women entrepreneurs. Shoprite also creates opportunities for its customers to become involved in philanthropic initiatives through projects such as Pretty Things for Little Things (where clothes, 
blankets and toys are made and distributed to needy children), trolley collection campaigns and gift-wrapping services, where proceeds go towards charity (Shoprite, 2014).

- Environment

Shoprite has adopted the principles of waste avoidance first, followed by reduction, re-use and recycling (Shoprite, 2011). Steps have been taken to manage electricity consumption (Shoprite, 2012), a state of the art grey-water system has been installed at a distribution centre (Shoprite, 2013) and food waste has been minimised while recycling of cardboard and plastic has risen (Shoprite, 2014). It has collaborated with its carrier bag supplier to increase the use of recycled plastics to $100 \%$ (Shoprite, 2014).

\subsubsection{Sustainability}

Shoprite recognises that sustainability should be a core aspect of corporate governance to ensure long-term success (Shoprite, 2010) and therefore established a Social and Ethics Committee to ensure responsible, ethical and sustainable operations (Shoprite, 2012). In the 2014 integrated report, Shoprite elaborated and indicated that their context of sustainability means focusing on customers, employees, the environment, suppliers, as well as the communities served (Shoprite, 2014) (see TABLE 14).

TABLE 14: Shoprite sustainability frequencies from 2010 to 2014

\begin{tabular}{lcccccc}
\hline & 2014 & 2013 & 2012 & 2011 & 2010 \\
\hline Frequency of 'sustain' & 29 & 21 & 23 & 9 & 21 \\
\hline
\end{tabular}

Source: Authors compiled using data from Shoprite (2010; 2011; 2012; 2013; 2014)

\subsection{Clicks}

\subsubsection{Stakeholders}

The Clicks annual reports contain many different reports in their non-financial information; however, many of the reports mainly focus on the group performance, rather than what has been done for stakeholders. The only report that focuses on stakeholders is the social and ethics committee report, illustrating more of a shareholder focus as opposed to general stakeholders (Clicks, 2010; 2011; 2012; 2013; 2014).

\section{- Customers}

Clicks has moderately mentioned its customers (see TABLE 15); however, part of its strategic objectives is to create a great customer experience and to drive customer loyalty through its ClubCard loyalty programme, and as part of its values it is passionate about customers (Clicks, 2014). The ClubCard loyalty programme is one of the biggest programmes in South Africa and has grown steadily over the period reviewed, from 3 million to 4.7 million active card holders. A total of R240 million was given back to customers in cash-back vouchers in 2014, amounting to a total payback of over R1.1 billion over the five years (Clicks, 2014). 
Gregory \& Chasomeris

TABLE 15: Clicks stakeholder frequencies from 2010 to 2014

\begin{tabular}{|c|c|c|c|c|c|c|c|c|c|c|c|c|}
\hline & \multicolumn{2}{|c|}{2014} & \multicolumn{2}{|c|}{2013} & \multicolumn{2}{|c|}{2012} & \multicolumn{2}{|c|}{2011} & \multicolumn{2}{|c|}{2010} & \multicolumn{2}{|c|}{ Total } \\
\hline & $F$ & $\%$ & $F$ & $\%$ & $F$ & $\%$ & $F$ & $\%$ & $F$ & $\%$ & $F$ & $\%$ \\
\hline $\begin{array}{l}\text { Customers/ } \\
\text { Consumers }\end{array}$ & 50 & $22 \%$ & 52 & $21 \%$ & 69 & $21 \%$ & 61 & $20 \%$ & 50 & $17 \%$ & 282 & $20 \%$ \\
\hline $\begin{array}{l}\text { Employees/ } \\
\text { Staff }\end{array}$ & 62 & $28 \%$ & 65 & $27 \%$ & 100 & $30 \%$ & 115 & $37 \%$ & 97 & $32 \%$ & 439 & $31 \%$ \\
\hline $\begin{array}{l}\text { Investors/ } \\
\text { Shareholders }\end{array}$ & 71 & $32 \%$ & 78 & $32 \%$ & 100 & $30 \%$ & 88 & $29 \%$ & 79 & $26 \%$ & 416 & $30 \%$ \\
\hline $\begin{array}{l}\text { Society/ } \\
\text { Community }\end{array}$ & 7 & $3 \%$ & 7 & $3 \%$ & 11 & $3 \%$ & 5 & $2 \%$ & 16 & $5 \%$ & 46 & $3 \%$ \\
\hline Supplier & 4 & $2 \%$ & 9 & $4 \%$ & 18 & $5 \%$ & 15 & $5 \%$ & 13 & $4 \%$ & 59 & $4 \%$ \\
\hline Environment & 31 & $14 \%$ & 31 & $13 \%$ & 33 & $10 \%$ & 24 & $8 \%$ & 48 & $16 \%$ & 167 & $12 \%$ \\
\hline Total & 225 & $100 \%$ & 242 & $100 \%$ & 331 & $100 \%$ & 308 & $100 \%$ & 303 & $100 \%$ & 1409 & $100 \%$ \\
\hline
\end{tabular}

Source: Authors compiled using data from Clicks (2010; 2011; 2012; 2013; 2014)

- Employees

Clicks believes that an important business enabler is motivated and skilled staff, who operate in a values-driven culture that rewards them based on performance. In order to achieve success in this business enabler, they have embraced transformation and moved from a level 5 BBEદE score in 2010 (Clicks, 2010) to a level 3 in 2011, mainly as a result of a broad-based employee share ownership programme that was introduced (Clicks, 2011). The company has maintained a level 3 score, but has improved it from the lower end of the level to the upper end from 76.99 in 2011 to 80.54 in 2014. Proof of its efforts to transform is that Clicks was rated as most empowered company in the retail sector in a survey conducted by the Financial Mail in 2013 (Clicks, 2013). This has been achieved while increasing the number of workers from 7289 to 8089 , and maintaining an employee turnover rate of $19-22 \%$.

Clicks has also contributed a growing amount towards its bursary scheme that aids university students in paying for tuition and learning resources. Every year in excess of R40 million has been invested in learning and skills development for employees. A wellness programme is offered to permanent employees and their dependants, providing independent, confidential, professional counselling and advisory services. Clicks attained an employee satisfaction rating of $65 \%$ in 2012 (Clicks, 2012) and was ranked first in the retail sector and within the top ten employers nationally by the Top Employers Institute in 2014 (Clicks, 2014).

\section{- Suppliers}

There has been little evidence that illustrates Clicks' focus on suppliers. In the periods reviewed, however, the annual reports did indicate that Clicks prefers to source merchandise from locally based and empowered suppliers, showing that it does support the local community.

\section{- Investors (Shareholders)}

In each year analysed it was noted that Clicks highlighted performance statistics for shareholders in several reports contained in the annual report to illustrate the growth in the company and value 
given back to shareholders (see TABLE 16). Its return on equity has remained the highest of the sector throughout the period reviewed.

TABLE 16: Clicks performance statistics from 2010 to 2014

\begin{tabular}{lccccc}
\hline & 2014 & 2013 & 2012 & 2011 & 2010 \\
\hline $\begin{array}{l}\text { \% increase in turnover } \\
\text { \% increase in diluted headline earnings }\end{array}$ & $9.2 \%$ & $13.6 \%$ & $9.2 \%$ & $6.2 \%$ & $9 \%$ \\
per share & $190 \mathrm{c}$ & $168 \mathrm{c}$ & $152 \mathrm{c}$ & $125 \mathrm{c}$ & $106 \mathrm{c}$ \\
$\begin{array}{l}\text { Dividends per share } \\
\text { Return on equity }\end{array}$ & $55 \%$ & $54.52 \%$ & $51 \%$ & $67.44 \%$ & $49.4 \%$ \\
\hline
\end{tabular}

Source: Authors compiled using data from Clicks (2010; 2011; 2012; 2013; 2014)

- General Society

Clicks invested just over $1 \%$ of profit after tax on CSR activities in each of the years reviewed. Furthermore, millions have been spent on enterprise development initiatives. Some of the activities that have been focused on include being collection points for state patient medication, offering free clinic services to mothers whose babies were born in state hospitals and who do not have medical cover, donating surplus stock and other items to charity, and donating to other beneficiaries that aid hearing-impaired individuals, child welfare and medical education.

\section{- Environment}

Clicks has dedicated itself to responding to climate change. Its focuses are on energy efficiency, water efficiency, water and waste management and distribution network optimisation (Clicks, 2014). It has been involved in recycling items such as plastic, paper and cardboard. In 2013 an initiative was implemented that involved capturing waste water from air-conditioning towers and recycling it to be used to flush toilets, resulting in about 80000 litres of water being saved in 2013 and 2014 (Clicks 2013; 2014). Carbon emissions have increased by 12000 metric tonnes since 2010; however, this is partly attributable to the fact that the group has grown by just over 70 stores over this period.

\subsubsection{Sustainability}

Clicks aims to create sustainable long-term shareholder value by utilising a retail-led health, beauty and wellness business model. The company reports that it uses its annual reports to demonstrate how shareholder value is being sustained over the time period. As such, the annual reports illustrate the material issues that have impacted or aided performance of the company and its sustainability for the short, medium and long term.

\section{CONCLUSION}

It is evident from the findings that all four companies have considered each of the six major stakeholders, but each to different extents. They each also consider sustainability.

SPAR's main concentration appears to be on its employees. It has also been established that its long-term goal is that of sustaining the group, with a concentration on the key stakeholders. 
SPAR, therefore, does not focus solely on shareholder wealth, nor does it focus on general stakeholder wealth, but rather on ensuring that the company itself is sustained. It is consequently concluded that, based on the period reviewed, SPAR's prevailing purpose is closest to that of the EMS model.

Pick $\mathrm{n}$ Pay appears to have a very strong focus on customers through differentiating itself based on its brand and loyalty programme. Despite this acknowledged attention, it does have a strong focus on sustainability of the group. Management has mentioned that without a certain extent of focus on stakeholders and their involvement, Pick n Pay would not be sustainable in the long term. The group therefore does not focus solely on shareholder wealth, nor on general stakeholder wealth, but rather on ensuring that the company itself is sustained. It is consequently concluded that, based on the period reviewed, Pick n Pay's prevailing purpose is closest to that of the EMS model.

In the 2013 integrated report, Shoprite states: 'the raison d'être of any business is to make a profit [but] in our modern society that can no longer happen in isolation' (Shoprite, 2013:11). This indicates that Shoprite believes that the objective of a business cannot merely be to make profits but rather that something over and above this needs to be done too. The neoclassical model is therefore not applicable. The five-year analysis of Shoprite reveals that Shoprite's main emphasis is on customers through offering low-cost solutions in order for its business to remain sustainable. As such, the EMS model is the closest fit.

Lastly, Clicks, although not ignoring other stakeholders, has a strong focus on shareholders and creating value and returns for them, as its aim is to demonstrate how shareholder value is being sustained. While it does have a strong focus on employees, most of the annual report is aimed at illustrating to shareholders how their value has been increased year-on-year. Its focus, however, is not simply to make profits but rather to make these profits and sustain the group for the long term so that profits can continue to be made and distributed to shareholders. Therefore, it is concluded that the EMS model has been applied, but unlike other businesses in the sector, Clicks prefers to focus on shareholders, with less focus on other stakeholders.

Overall, it is evident that all the entities in the food and drug retail sector of the JSE appear to be following the entity maximisation and sustainability model, as opposed to the neoclassical or conscious capitalism model. It has been discovered that their approach to EMS differs, however. Pick n Pay and Shoprite, for instance, focuses more on customers (although the former through differentiation and the latter through a low-cost strategy), SPAR focuses on employees, and Clicks focuses on shareholders in applying its approach.

\section{LIST OF REFERENCES}

Abdur-Rahman, P. (2011). What are the assumptions behind Neoclassical Economics? Available: http://prahman.wordpress.com/2011/06/24/what-are-the-assumptions-behind-neoclassical-economics/ [Accessed 22 August 2014].

Aburdene, P. (2013). The Competitive Advantage of Conscious Capitalism. MWorld, 12, pp. 3-4.

Bocken, N., Short, S., Rana, P. \& Evans, S. (2013). A value mapping tool for sustainable business modelling. Corporate Governance: The International Journal of Effective Board Performance, 13, pp. 482-497. 
Budan, M. (2013). A Higher Consciousness. Conference Board Inc.

Burke, R.J., Martin, G. \& Cooper, C.L. (2011). Corporate Reputation Managing Opportunities and Threats, Surrey, Gower.

Clicks (2010). Clicks Group Limited Annual Report 2010. South Africa. Available:

http://www.clicksgroup.co.za/IRDownloads/AnnualReport2010/Clicks\%20AR10\%20LowRes.pdf [Accessed 1 March 2015].

Clicks (2011). Clicks Group Limited Integrated Annual Report 2011. South Africa.

Available:http://www.clicksgroup.co.za/IRDownloads/AnnualReport2011/T4IB03367_Clicks\%20 AR\%202011.pdf [Accessed l March 2015].

Clicks (2012). Clicks Group Limited Integrated Annual Report 2012 South Africa. Available: http://www.clicksgroup.co.za/IRDownloads/AnnualReport2012/clicks-IAR-2012.pdf [Accessed 1 March 2015].

Clicks (2013). Clicks Group Limited Intergrated Annual Report 2013 South Africa.

Available:http://www.clicksgroup.co.za/IRDownloads/AnnualReport2013/Clicks\%20IAR13\%20w eb.pdf [Accessed 1 March 2015].

Clicks (2014). Clicks Group Limited Integrated Annual Report 2014 South Africa. Available: http://www.clicksgroup.co.za/IRDownloads/AnnualReport2014/Clicks-IAR14-web.pdf [Accessed 1 March 2015].

Coates, B.E. (2013). Embedding Leadership driven Conscious Capitalism into Corporate DNA. Advances in Management, 6, 14-24.

Dos Santos, M.A.O., Svensson, G. \& Padin, C. (2014). Implementation, monitoring and evaluation of sustainable business practices: framework and empirical illustration. Corporate Governance: The international journal of business in society, 14, 515-530.

Elson, C.M. (2010). Five Reasons to Support Shareholder Primacy. NACD Directorship, 36, 63.

Global Reporting Initiative. (2015). GRI Empowering Sustainable Decisions Available:

https://www.globalreporting.org/information/about-gri/Pages/default.aspx [Accessed 4 November 2015].

Halburd, C. (2014). What is the purpose of a corporation? Governance Directions, 66, pp. 668671.

Høgevold, N.M., Svensson, G., Klopper, H.B., Wagner, B., Valera, J.C.S., Padin, C., Ferro, C. \& Petzer, D. (2015). A triple bottom line construct and reasons for implementing sustainable business practices in companies and their business networksnull. Corporate Governance: The International Journal of Business in Society, 15, pp. 427-443.

Høgevold, N.M., Svensson, G., Wagner, B., Petzer, D.J., Klopper, H.B., Varela, J.C.S., Padin, C. \& Ferro, C. (2014). Sustainable business models: Corporate reasons, economic effects, social boundaries, environmental actions and organizational challenges in sustainable business practices. Baltic Journal of Management, 9, pp. 357-380.

Ireland, P. (2005). Shareholder Primacy and the Distribution of Wealth. Modern Law Review, 68, pp. 49-81.

Jones, G.R. \& George, J.M. (2011). Contemporary Management, Boston, McGraw-Hill/Irwin. 
Jones, T.M. \& Felps, W. (2013). Shareholder Wealth Maximization and Social Welfare: A Utilitarian Critique. Business Ethics Quarterly, 23, pp. 207-238.

Keay, A. (2008). Ascertaining The Corporate Objective: An Entity Maximisation and Sustainability Model. Modern Law Review, 71, pp. 663-698.

Lamb, C.W., Hair, J.F., McDaniel, C., Boshoff, C., Terblanche, N.S., Elliot, R. \& Klopper, H.B. (2010). Marketing, Cape Town, Oxford University Press.

Loderer, C., Roth, L., Waelchli, U. \& Joerg, P. (2010). Shareholder Value: Principles, Declarations, and Actions. Financial Management, 39, pp. 5-32.

Mackey, J. (2011). What Conscious Capitalism Really Is. California Management Review, 53, pp. 83-90.

Magaro, M. M. (2010). Two Birds, One Stone: Achieving Corporate Social Responsibility Through the Shareholder-Primacy Norm. Indiana Law Journal, 85, pp. 1149-1167.

0'Toole, J. \& Vogel, D. (2011). Two and a Half Cheers for Conscious Capitalism. California Management Review, 53, pp. 60-76.

Omran, M., Atrill, P. \& Pointon, J. (2002). Shareholders versus stakeholders: corporate mission statements and investor returns. Business Ethics: A European Review, 11, pp. 318-326.

Pick N Pay. (2010). Pick n Pay Annual Report 2010. South Africa. Available:

http://financialresults.co.za/2010/pnp_ar2010/downloads/pnp_ar2010.pdf [Accessed 1 March 2015].

Pick N Pay. (2011). Integrated Annual Report 2011 Pick n Pay. South Africa. Available:

http://www.picknpay-

ir.co.za/financials/annual_reports/2011/downloads/picknpay_ar2011.pdf [Accessed 1 March 2015].

Pick N Pay. (2012). Pick n Pay Integrated Annual Report 2012. South Africa. Available:

http://www. picknpay-

ir.co.za/financials/annual_reports/2012/downloads/integrated_ar/pnp_integrated_ar.pdf

[Accessed 1 March 2015].

Pick N Pay. (2013). Pick n Pay Integrated Annual Report 2013. South Africa. Available:

http://www.picknpayinvestor.co.za/financials/annual_reports/2013/Integrated_Annual_Repor t_2013.pdf [Accessed 1 March 2015].

Pick N Pay. (2014). Pick n Pay Integrated Annual Report 2014. South Africa. Available:

http://picknpayinvestor.co.za/downloads/2014/Pick_n_Pay_IAR_2014.pdf [Accessed 1 March 2015].

Queen, P. (2015). Enlightened Shareholder Maximization: Is this Strategy Achievable? Journal of Business Ethics, 127, 683-694.

Rauch, D. (2011). Conscious Capitalism: A Better Road Map. California Management Review, 53, pp. 91-97.

Robbins, S.P., Judge, T.A., Odendall, A. \& Roodt, G. (2011). Organisational Behaviour Global and Southern African Perspectives, Cape Town, Pearson. 
Sandling, J. (2014). What is Conscious Capitalism? Available:

http://jonathansandling.com/what-is-conscious-capitalism/ [Accessed 28 November 2015].

Schawbel, D. (2013). John Mackey: Why Companies Should Embrace Conscious Capitalism. Available: http://www.forbes.com/sites/danschawbel/2013/01/15/john-mackey-whycompanies-should-embrace-conscious-capitalism/ [Accessed 28 November 2015].

Schiller, B.R. (2011). Essentials of Economics, New York, McGraw-Hill / Irwin.

Seay, S.S. (2015). HOW INCORPORATING A SUSTAINABLE BUSINESS MODEL CREATES VALUE. Business Studies Journal, 7, pp. 46-60.

Shoprite. (2010). Shorite Holdings Ltd Annual Report 2010 Geared for Growth. South Africa.

Available: www.shopriteholdings.co.za/investorcentre/documents/2010/2010_shopritear_eng. pdf [Accessed 1 March 2015].

Shoprite. (2011). Shoprite Holdings Ltd Competing With the Right Strategy Integrated Report 2011. South Africa. Available:www.shopriteholdings.co.za/InvestorCentre/Documents/2011/ Annual\%20Report\%202011\%20English_web.pdf [Accessed l March 2015].

Shoprite. (2012). Shoprite Holdings Ltd Africa's Largest Food Retailer Integrated Report 2012. South Africa. Available: http://www.shopriteholdings.co.za/InvestorCentre/Documents/ June_2012_Annual_Financial_Statements.pdf. [Accessed 1 March 2015].

Shoprite. (2013). Shoprite Holdings Ltd Integrated Report 2013. South Africa. Available: http://www.shopriteholdings.co.za/investorcentre/documents/2013/shoprite_afs_2013.pdf. [Accessed 1 March 2015].

Shoprite. (2014). Shoprite Holdings Ltd Integrated Report 2014 Low Price Leadership for Tomorrow's Customer. South Africa. Available: http://www.shopriteholdings.co.za/ InvestorCentre/Documents/2014/IntergratedReport2014/5206_ShopriteAnnualFinancialStatem ents_Web.pdf. [Accessed 1 March 2015].

Šimanskienè, L. \& Paužuolienė, J. (2010). CORPORATE SOCIAL RESPONSIBILITY BASED ON SUSTAINABLE BUSINESS. Human Resources: The Main Factor of Regional Development, pp. 324331.

Sisodia, R.S. (2011). Conscious Capitalism: A BETTER WAY TO WIN. California Management Review, 53, pp. 98-109.

Sisodia, R.S. (2013). Understanding the Performance Drivers of Conscious Firms. California Management Review, 55, pp. 87-96.

Spar. (2010). SPAR 2010 Annual Report. South Africa. Available:

https://www.spar.co.za/getattachment/86b02ac3-le91-4450-ad08-acbbaffdf401/000000000000-0000-0000-000000000000-(1).aspx. [Accessed 1 March 2015].

Spar. (2011). The SPAR Group Ltd Integrated Annual Report for the year ended 30 September 2011. South Africa. Available: https://www.spar.co.za/getattachment/e98f0312-a78f-42649967-4608883c59cc/00000000-0000-0000-0000-000000000000.aspx. [Accessed l March 2015].

Spar. (2012). The SPAR Group Ltd Integrated Annual Report for the year ended 30 September 2012. South Africa. Available: https://www.spar.co.za/getattachment/36683948-50db-430e923e-932547bd7581/00000000-0000-0000-0000-000000000000-(5).aspx. [Accessed 1 March 2015]. 
Spar. (2013). The SPAR Group Ltd Integrated Annual Report for the year ended 30 September 2013. South Africa. Available: https://www.spar.co.za/getattachment/a6164404-0e5b-4110bdd4-bf921af866be/00000000-0000-0000-0000-000000000000-(7).aspx. [Accessed 1 March 2015].

Spar. (2014). SPAR Integrated report 2014. South Africa. Available:

https://www.spar.co.za/getattachment/fcl6bl38-ed55-4d20-9305-ef34e24c7af8/0000000000000-0000-0000-000000000000-(11).aspx [Accessed l March 2015].

Stout, L.A. (2013). The Toxic Side Effects Of Shareholder Primacy. University of Pennsy/vania Law Review, 161, pp. 2003-2023.

Sundaram, A.K. \& Inkpen, A.C. (2004). The Corporate Objective Revisited. Organization Science, 15, pp. 350-363.

United Nations (1987). Our Common Future - Brundtland Report.

Vranceanu, R. (2014). Corporate profit, entrepreneurship theory and business ethics. Business Ethics: A European Review, 23, pp. 50-68.

Wagner, B. \& Svensson, G. (2014). A framework to navigate sustainability in business networks: The transformative business sustainability (TBS) model. European Business Review, 26, pp. 340 367.

Waligo, V.M., Clarke, J. \& Hawkins, R. (2014). The 'Leadership-Stakeholder Involvement Capacity’ nexus in stakeholder management. Journal of Business Research, 67, pp. 1342-1352.

Wang, C. (2013). Conscious Capitalism Firms: DO THEY BEHAVE AS THEIR PROPONENTS SAY? California Management Review, 55, pp. 60-86.

Young-Ferris, A. (2015). Conscious Capitalism: A Higher Purpose For Business?. Available: http://sydney.edu.au/business/alumni/magazine/world/conscious_capitalism_a higher_purpose_for_business [Accessed 29 November 2015]. 